\title{
THE PAST AND PRESENT OF THE SAMOGITIAN LANGUAGE
}

\author{
Juozas PABRĖŽA \\ Šiauliai University
}

\section{Historical overview}

An essential question has been repeatedly raised since olden times: is Samogitian a language or a dialect? Before the appearance of standard Lithuanian, the concept of the Samogitian language prevailed. Quite a few Samogitians wrote their works in Samogitian. The $19^{\text {th }} \mathrm{c}$. boasts a particularly large number of such works. In that period the concern and efforts to create standard Lithuanian on the basis of the Samogitian dialect were particularly obvious. The language and the spelling of Dionizas Poška, Silvestras Valiūnas and Simonas Stanevičaus, all of them originally being South Samogitians, were oriented towards their native Dünininkai dialect. Three of the most prominent Samogitians of the $19^{\text {th }}$ c. - Jurgis Ambraziejus Pabrèža, Simonas Daukantas and Motiejus Valančius - employed the North Samogitian Dounininkai dialect in their writings.

The creator of the standard Samogitian language J. A. Pabrèža wrote: "A Samogitian will never agree about the language either with a Lithuanian, a Prussian or a Latvian.” (Subačius 1996: 54)

Juozas Čiulda, the author of the most solid grammar of the Samogitian language of the time, written in Polish in 1854 (Trumpi samprotavimai apie žemaičiu kalbos gramatikos taisykles - "Brief Reasoning about the Rules of the Samogitian Language") consistently used the concept of the Samogitian language, and at the end of his book affirms this by stating the following: "These are my speculations about the Samogitian language. How I wish somebody knew more about this language! He would be able to formulate and provide more precise rules.” (Čiulda1993: 357)

The importance of the works of the above-mentioned Samogitians of the $19^{\text {th }} \mathrm{c}$. was so evident that the Samogitian language almost became the basis for standard Lithuanian; that would have allowed the Samogitian language to become the national language of the whole of Lithuania.

After standard Lithuanian had been formed on the basis of the SouthWest Aukštaitian subdialect, other linguistic systems usually were referred to as dialects. Most Lithuanian dialectologists now tend to regard the Samogitian linguistic system as a dialect of Lithuanian. Antanas Salys (1933: 22-26) has tried to establish the time of diverging of Lithuanian dialects. On the basis of the development of the combination of $* t j,{ }^{*} d j$, he arrives at a conclusion that our main dialects diverged around the $15^{\text {th }} \mathrm{c}$. This view is supported by 
a number of linguists. Zigmas Zinkevičius, while admitting that Samogitian is the dialect that has moved furthest from the model of old Lithuanian, tends to associate it with a Curonian substratum and treats the Samogitian dialect, especially its North-West variety, as a Lithuanian dialect "in Curonian lips" (Zinkevičius 1981: 12-18; 2006: 65, 207-226).

The first linguist who cautiously tried to oppose such late divergence of dialects and such origins of Samogitian dialect, was Aleksas Girdenis. First of all, he proved that the date, identified by A. Salys, was established without a deeper analysis. A. Girdenis (1971: 81-86) moves this date further into the past and argues that our dialects must have diverged already by the $13^{\text {th }} \mathrm{c}$., i.e. before the emerging of the Lithuanian state.

Later A. Girdenis made a more courageous step. He started supporting archaeologist Adolfas Tautavičius, who claims that already in the $4-5^{\text {th }} \mathrm{c}$. there was a union of Samogitian tribes, with their own customs of burying their dead, original culture, their own territory and probably their own language (Tautavičius 1981: 27-33). A major influence of the Curonian language on Samogitian dialect also started to seem doubtful, because a number of specific Samogitian linguistic features (e.g., stress retraction, reduction of endings) could be more easily and more convincingly explained not by linguistic contacts but by internal causes (Girdenis 1981: 19-26; Pabrèža 1986: 53-59). Mostly on the basis of the development of the end of the word, A. Girdenis rightfully believes that the Samogitians had to start diverging in terms of their language not later than in the $7^{\text {th }} \mathrm{c}$., while the first phonetic features of the Samogitian language could have appeared even earlier-probably even in the $5^{\text {th }} \mathrm{c}$., which is most often mentioned by archaeologists. Most probably, there was no such thing as a common Lithuanian proto-language: the Samogitians, just as Semigallians, Selonians, maybe also Curonians and Lithuanians, were speaking one of the tribal East-Baltic languages. That means that languages and dialects had not diverged but converged with each other, because linguistic differences before the formation of the Lithuanian state had to be much greater than in later and present times (Girdenis 1994: 5-20).

Aleksas Girdenis and Juozas Pabrèža have discussed the relationship between the Samogitian language and dialect more than once. In their book Žemaičiu rašyba ("Samogitian Spelling") they state: "On the basis of the tradition which is still alive until now, one can rightfully use the term the Samogitian language, while the term Samogitian dialect should be left for the "pure" linguistic science. While writing or speaking Samogitian, dialect is not a suitable word, because in speech it means "pronunciation, an accent" (e.g.: ons šnek gerā žemaitěškā, tik anuo ta tarmie tuoki kap latvèška - 'He speaks 
Samogitian well, but his dialect (i.e. pronunciation) is the same as Latvian')." (Girdenis, Pabrèža 1998: 11) ${ }^{1}$

This is how Viktorija Daujote (Daujotytè) precisely and vividly describes the relationship between the language and the dialect: "With Samogitian words, sentences, hopefully also with intonations, I dive into the world which doesn't and can't exist without that language. For the science of linguistics it is a dialect, while for those who used to speak and are speaking it - it is a language. There is no contradiction here. I spoke a language, not a dialect. $\langle\ldots\rangle$ That means, that language is our mother tongue; a particular, native one. None of us would dare to "distort the language" while talking to our mother, to talk differently from the way we were used to talking at home." (Daujote 2015: 9-10)

Thus the answer to the question whether Samogitian is a language or $a$ dialect could be like this: both terms are good and can be used. If several linguistic systems are being compared, the term dialect suits perfectly, e. g., North Samogitian dialect, South Samogitian dialect, South Aukštaitian (Dzūkian) dialect, etc. However, if we talk or write about one linguistic system, we can definitely use the term the Samogitian language. On the whole, the terms language and dialect are very close concepts. Because the native dialect is one's native language, inherited from parents, from the place where you were born and grew up, where your true roots are. It is only later that you learn another, second language, i. e. standard national language. Ultimately, all languages are derived from certain dialects; that is why it is quite understandable that a dialect can be granted the status of a language (Aliūkaite 2013:9).

This paper argues that there is the Samogitian language with three distinct dialects (North Samogitian or Dounininkai, South Samogitian or Dūnininkai, west Samogitian or Donininkai), North Samogitian Telšiškiai and Kretingiškiai, South Samogitian Varniškiai and Raseiniškiai subdialects and a lot of smaller speeches and sub-speeches (see Figure 1).

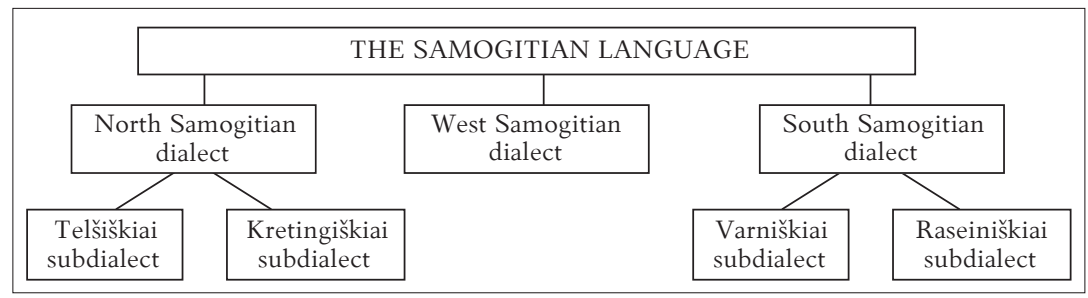

Figure 1. Dialects and subdialects of the Samogitian language

1 For more about the relationship between the Samogitian language and Samogitian dialect see Pabrèža 2012a: 48-49; 2017: 43-48. On the inaccuracy of terming the Samogitian language a dialect also see Bukantis 2002: 12. 


\section{Salient features of Samogitian}

Today it is universally recognised that the most important element of traditional Samogitian culture, that sets Samogitians apart from the rest and defines, identifies and represents Samogitian identity is the Samogitian language, its dialects and speeches ${ }^{2}$. The most salient signs of identity of the Samogitian language and proofs of its status of a language are as follows:

The Samogitian language differs a lot from both the standard Lithuanian language and other dialects of Lithuanian. In terms of the language, Samogitian differs from Aukštaitian more than East Slavonic Russian, Byelorussian and Ukrainian, South Slavonic Serbian and Croatian, West Slavonic Czech and Slovak, Estonian and Finnish, North German and Dutch. The fact that the Samogitians are more exceptional in terms of their language is supported by a universal agreement among the linguists and dialectologists that all Lithuanian dialects are first of all divided into two major segments: the Samogitian and the Aukštaitian ${ }^{3}$.

Another extremely important aspect of the identity of the Samogitian language is that it has at all language levels (i.e. phonetics, morphology, syntax and lexis) quite a number of unique, archaic, older qualities, sounds, forms and constructions, which cannot be found in today's standard Lithuanian or other dialects, are preserved ${ }^{4}$. Here are some such examples.

A substantial group of South-East Samogitians instead of nasal vowels $q, e, u, j$ in the standard language has preserved the older pronunciation of these vowels together with a consonant $n$, e. g., kánsnis/kộnsnis - Stand Lith kąsnis 'bite', drã̃nsus/drộnsọ̀s - drąsus 'brave', skẽnsti/skẹnnstẹ - skęsti 'to sink', švẽñsti/švệnste - švęsti 'to celebrate', ŝunste - siusti 'to send', gèrũn - geru (gen. pl.) 'good', linste - lịsti 'to crawl, creep', grĩnšte - grižžti 'to return'.

The Samogitians use affricates $\hat{c}$, $d \hat{z}$ much more rarely than standard Lithuanian or other dialects. On the whole, ancient Lithuanians didn't have the sounds $\hat{c}, d \hat{z}$ at all. Instead, they were pronounced $* t j,{ }^{*} d j$ (Zinkevičius 1994: 88). Today the Samogitians instead of $\tilde{c}, d \hat{z}$ in some forms of the words pronounce consonants $\hat{t}, \hat{d}$ quite close to the old combinations: jáut $\hat{e}-$ Stand Lith jaučiai 'oxen' jáutêms - jaučiams 'for oxen', žáltẽ —žalčiai 'grass-snakes', žáltẽ̃s - žalčiais 'with grass-snakes', kẽitọ - keičiu 'I am changing', kẽitâm keičiame 'we are changing', ártẫu - arčiau 'I would plough', mèdê-medžiai

2 On the linguistic self-awareness of the Samogitians see Kalnius 2012: 296-337.

3 It is interesting that Antanas Baranauskas, who was one of the first to divide Lithuanian dialects quite precisely, instead of the term the Aukštaitians used the term Lithuanians. Thus, according to A. Baranauskas - there are the Samogitians and the Lithuanians (Baranovskij 1898: 49-78).

4 On archaic qualities of the Samogitian language see Pabrèža 2012b:9-10; 2015: 86-89, 2018. 
'trees', mèdêms - medžiams 'for trees', gáidẽ - gaidžiai 'roosters', gáidẽs gaidžiais 'with roosters', âudọ - audžiu 'I am weaving', áudâm - audžiame 'we are weaving', skãudê — skaudžiai 'painfully'.

The Samogitians stand out also by the variety of stress and vivid pitch. A lot of Samogitian words, different from standard Lithuanian and other dialects, have two, three or even four stresses, e.g.: vẹštà - Stand Lith višta 'hen', bàsẹ - basi 'barefoot', sẽrgọ - sergu 'I am ill', blúogã - blogai 'badly', vélnẽ - velniai 'devils', šệlọmà - šiluma 'warmth', sèptĩnẹ - septyni 'seven', pàvãrkstọ - pavargstu 'I get tired', pârsimàlavũojusì-persidažiusi 'wearing too much makeup', nàbàprìgĩrdì-nebeprigirdi 'is hard of hearing'. The so-called laužtine priegaide $\left({ }^{\wedge}\right)$, a variant of the acute accent, a broken tone, typical of North Samogitians, is exceptional. The sounds with this pitch are pronounced clearly and strongly, i.e., the voice, after a sudden high rise, stops with a kind of explosion and is further pronounced as the same but a weaker, lower sound. Most often this broken pitch is used instead of the standard language acute accent or in syllables after the main old stress, e.g., dâkts - Stand Lith dáiktas 'thing', kârve - kárve 'cow', kûoks - kóks 'what', sied - sédi 'is sitting', trûkst - trúksta 'lacks', kãrklâ - kar̃klai 'willows', brẹidêm - bríedžiams 'for moose', sprúokstâm - sprogstame 'we are exploding'. The abundance of stress and emphatic pitches gives the Samogitian language extra dynamism, expression and vivacity. These stresses and pitches very clearly single out the word in the sentence, which means that they perform another important role - that of marking the boundaries between the words.

The Samogitians also have some unique archaic morphological and syntactic features. They have preserved older Dative sg. inflections $-u o,-i e$ of the $1^{\text {st }}$ and $3^{\text {rd }}$ declinations of nouns (cf. standard language $-u i$, -iai, -iui), which, depending on the territory, are pronounced -ou, - ẹi (in the North), $-u,-i$ (in the South), $-o,-e$ e (in the West), e.g.: mẹ̌sộu - Stand Lith miškui 'for the forest', tíevộu-tèvui 'to/for father', nàktệi-nakčiai 'for the night', vàgệi-vagiui (North) 'to the thief', mẹškû̀', tíevû', nàktî, vàgî (South), mẹškồ, tíevồ, nàktệ, vàgệ (West).

Next to usual forms of the verb, the Samogitians also use older athematic ones, e.g. lệikt / lĩkt-Stand Lith lieka 'remains', mệikt / mĩkt - miega 'sleeps', gệist / gî̀st-gieda 'sings', ẽit / ẽt-eina 'goes', skãust-skauda 'pains', bûsmabūsime 'we will be', dệrpsma - dirbsime 'we will work', šûokste - šoksite 'you will dance'.

The Samogitians have largely preserved the dual number, especially in the North and the West. The dual number is very much used not only with verbs, but also with pronouns, nouns, adjectives and even participles. Instead of the pronouns mudu, mudvi 'the two of us' the Samogitians have older forms vẽdu, vẽdvi, e.g., vẽdọ, vẽdve dẹrbâu, síedâu-Stand Lith mudu, mudvi dirbame, 
sédime 'the two of us are working, sitting', jọ.dọ, jộ.dvẹ dẹrbatâu, síedatâu-judu, judvi dirbate, sedite 'the two of you are working, sitting'. Other examples: dọ gerộujo vãkọ - du gerieji vaikai 'the two good children', dvẹ pộikè mêrgẹ - dvi gražios mergaitès 'two beautiful girls', vếdọ abọ́.dọ esâu tện bộ.vộọ - mudu abudu esame ten buve 'the two of us/both of us have been there'.

With respect to word derivation, some suffixes used in a particular way and preferred by the Samogitians can be mentioned. Family name suffixes are of great variety and have different meanings. The Suffix -ale is preferred to describe girls and unmarried women, especially in Northern and Western Samogitian speeches: Petkãle - Stand Lith Petkutè, Vaitkãle - Vaitkutè, Šakãle -Šakytè, Gèdgaudãle -Gedgaudaitè. In more Southern parts of Samogitia, the suffix -ike is more used in the family names of girls, e.g., Petkẹke Petkutè, Bọtkệke - Butkutè, Norvaišìiki - Norvaišaitè, the Suffixes -ūtis, -uitis are used in Samogitia in the family names of teenage boys: Petkûtis - Petkus, Vàlọzûutis - Valužis, Kàzragûitis - Kazragis, Pàbrẹžûitis - Pabrėža.

Today in Samogitia they still very often use an original intermediary aspect of the verb, which is formed by adding adverbs with faded meaning and reinforcing words žẽmèn, laũk, šaliñ, lýgiai, kietaĩ, etc. to the verbs without a prefix. Sentences with such aspect forms show that the action has not happened yet, but is approaching its unavoidable finish: nu_bãda pradiejâu slabnîete žèmện-Stand Lith nuo bado pradëjau visai silpnèti 'because of hunger started getting completely weak', tievã lis mệršt žèmện-tèvelis miršta ir greitai numirs 'dad is dying and soon will be dead', vuo_karšttîbe bûs, ãkis sprûokst iš kaktũos lãuk - o karštybe bus - akys sprogsta iš kaktos (tiesiog veržte veržiasi) 'and the heat will be - the eyes are popping out of the forehead, simply pushing out', plieš dràbuž̀̀̀ šàlẹn - plèšia drabužius - veikiausiai liks nuogas 'is tearing his clothes - probably will remain naked', vaẑộu mãma i_tộrgọ, jême mùnì lígê - važiuoja mama j̣ turgu - būtinai pasiima ir mane 'mother goes to the market - surely takes me together', darîk taz dọrìs kẹitã - uždaryk duris visai 'close the door completely'.

The Samogitian vocabulary is rich. There are some words that are not used in the standard language at all and are hardly understood by the speakers of other dialects. Here are a few examples of such words: krãme - Standard Lith galva 'head', plónymas - smilkinys 'temple', stáibis - blauzda 'calf', krùpis or kriùpis - rupūžèe 'toad; a small child', lẽdspira - baltoji kiele 'kind of bird', ašóklis ar vašóklis - raudonasis serbentas 'red currant', lẽdžinga - pačiūža 'skate', žiógspira - pjuvena 'sawdust', kùšinti-liesti, judinti 'to touch, to move', liur̃̌šti - plepèti 'to chat', sliñkas - tingus 'idle', drúktas - storas 'thick, fat', apént, apéntais - vèl, iš naujo 'again', nõgniai - labai, smarkiai 'very, strongly', véikiai-greitai 'very quickly'. 


\section{The current development of Samogitian}

The rebirth and development of Samogitian writing helps a lot in strengthening and consolidating the Samogitian language. Today quite a few newspaper articles and fiction works have been published on the basis of Samogitian spelling standardised by Aleksas Girdenis and Juozas Pabrèža (Pabrèža 1991: 1-43; Girdenis, Pabrèža 1998: 1-80). They are particularly numerous in the journal Žemaičiu žemè ('Samogitian Land') and other periodicals published in various regions of Samogitia between 1993 and 2016. More than one book in Samogitian has been published and enjoyed by readers. Edvardas Rudys and Teklè Džervienè are among the best, who write prose in their native North Samogitian language. In 1996, E. Rudys' collection of memoir stories Kuotré was published, followed by a collection of short stories Sémuona malūnā in 2011. T. Džervienè's short story Akmou so velne piedo (2000) is considered to be the first work of erotic prose in Samogitian. In 2011, a solid collection of works of this author Žali žuolele appeared. The largest in volume (514 pages) is Donatas Butkus' book Kā žemé bova brongesne ož douna, a collection of 9 stories, written in his native Samogitian of the Plunge region and published in 2016. Poems written and published in Samogitian are especially numerous. In 1998, the first anthology of Samogitian poetry Savo muotinu kalbo... was compiled and published. There are even 41 past and present poets who write in Samogitian. The Samogitian poet Apolinaras Petras Bagdonas, who was born and brought up in Užventis, South Samogitian region, and who after the war was living and writing in the USA, has to be singled out. A lot of his poems, written in the native Samogitian Dünininkai language, can be found in the books Pruo gintara longa (1978), Medviegale pasaka (1979), Gīvenims - najūkā (1982), Lèkèma laiptās (1991). Viktorija Daujote (Daujotytè), the famous literary science specialist and the author of numerous books, pleasantly surprised by producing four poetry books written in her native South Samogitian Varniškiai language: Balsā ūkūs (2010), Gīvenu vìna (2012), Tatā pariejau (2015), Žìmèni vobelie (2016). A lot of beautiful verse has been written in Samogitian and published in various newspapers, journals and other sources by Stasys Anglickis, Juozas Elekšis, Aleksas Girdenis, Birute Lengvenienè, Vaclovas Pocius, Eugenijus Zabitis, Justinas Kubilius, Edmundas Untulis, Irena Daubarienė, Dalia Zabitienė and many others. All writings in Samogitian have been crowned by the newest and most comprehensive anthology of Samogitian fictional literature Žemaitē / Žemaičiai (2018), which contains 48 prose, poetry and drama authors ${ }^{5}$. The words of a famous Samogitian poet in his introductory

5 For more on the reborn Samogitian writing and publications in Samogitian see. Pabreža 2018a: 119-139. 
article to the anthology Žemaičiu pasisakymas are especially meaningful and worth remembering: "It is necessary to revive all those riches of the Samogitian language, which, with the introduction of the standard written language, were pushed aside; it is necessary to make use of all those jewels of the language, which are still possessed by the Samogitian folks. There is only one language, in which all the writers in the world write best of all, and it is their mother tongue. The Samogitians first of all have to use their tongue to the limit and only then use someone else's, but not vice versa.” (Anglickis 1938: 13)

\section{The Samogitian identity}

Another exceptional aspect of Samogitian identity related to their language has to be emphasised. Today identification and self-identification via the native Samogitian language is very important and pronounced in Samogitia. Most Samogitians see dialectal speech as their true native language. Participating in the project "Modern Geolinguistic Research in Lithuania: Optimisation of the Network of Locations and Interactive Dissemination of Information", implemented by the Institute of the Lithuanian Language between 2011 and 2013, the author of the present paper and his students interviewed 247 people of various generations in 25 North Samogitian Telšiškiai localities (Skuodas, Mažeikiai, Akmenè regions). All 247 respondents taking part in the research indicated Lithuanian as their native language; however, even 233 additionally also singled out the Samogitian language, in which part of them can read (142) and write (20).

The Samogitian language is a great value for most Samogitians. A person, speaking Samogitian, is likely to be described and judged positively. The above-mentioned research shows that out of the 317 answers, the majority (113) described a person speaking Samogitian as somebody who respects the native language or is patriotically minded (68). Other positive judgements of the Samogitian speaker are connected with childhood, the native land, relatives, Samogitian features and Samogitian identity proofs: "I was born this way, I was brought up this way, I am used to it" (35) "a true Samogitian" (22), "this is how one should speak" (10), "a Samogitian" (10), "a solid, true-born Samogitian", (6), "I haven't turned my coat" (3), "a stubborn Samogitian", "a true Samogitian", "a thoroughbred Samogitian", "not a hypocrite" (1) etc. Only a few respondents associated dialectal speech with an image of a countryman (9), with older people (6) or with uneducated people (2) (Mikuleniené, Meiliūnaite 2014: 136-137).

On the whole the prestige of the Samogitian language is strong and still growing. It is interesting that in many places in Samogitia the prestige of the Samogitian language is stronger among the younger generation than among 
middle-aged people. Here are some impressions experienced in North Samogitia, in the Skuodas region, during the implementation of the above-mentioned project by the author of the present paper. Donatas Valančiauskas, born in 1961, the elderman of Aleksandrija, said the following: Vākã î̀ dẹdesnẹ žemãitể nègọ tievã 'Children are bigger Samogitians than their parents'. Dovydas Baublys, born in 1992, a very popular chairman of Bugieniai community, Mažeikiai region (2012), defined as one of his most important tasks and obligations to speak only Samogitian in all community meetings and other events (Pabrèža 2018b: 190-191).

The words of A. Girdenis, a true lover and researcher of the Samogitian language, shouldn't be forgotten: "One's homeland starts from the native yard, while the native speech is the one you get from your mother...<...> until now I feel that I am thinking, day-dreaming and even dreaming not in the language that I learned from books and teachers... And I firmly believe: our true native tongue is our dialect. $\langle\ldots\rangle$ Language and dialect are not simply systems of signs, it is a particular model of the world, unique windows, through which we look at the world. The more such windows, the more unique looks, the bigger the guaranty that both the nation and the whole of humankind will find out more about the world and itself." (Girdenis 1990: 2-3)

\section{Conclusions}

Today it is universally recognised that the most important and exceptional element of traditional Samogitian culture, most vividly defining, identifying and representing Samogitian identity is the Samogitian language, its dialects, subdialects and speeches. The most important signs of identity of the Samogitian language and proofs of its status as a language are as follows:

1) Samogitian dialectal speech clearly differs both from standard Lithuanian and other Lithuanian dialects; this oneness of the Samogitian language is demonstrated by a unanimous agreement among linguists to divide all Lithuanian dialects first of all into two big groups: the Samogitians and Aukštaitian (and earlier into the Samogitians and Lithuanians).

2) The Samogitian language has all the most important levels of any language (phonetics, morphology, syntax and lexis), and at all these levels the Samogitian has preserved a lot of unique, archaic features, sounds, forms, constructions, which do not exist in standard Lithuanian or in other dialects.

3) The Samogitians have standardised spelling with definite rules, according to which a lot of articles are published in their own press and in books of fiction. 
4) Today identification and self-identification via the native Samogitian language is very pronounced and important in Samogitia, most Samogitians view dialectal speech as their native language, while a person speaking Samogitian is most often seen and defined positively as the one respecting the native language, patriotically minded, etc. On the whole, the prestige of the Samogitian language is strong and still growing.

\section{References}

Aliūkaitè, Daiva. 2013.

Anglickis, Stasys. 1938.

Baranovskij, Antonij. 1898.

Bukantis, Jonas. 2002.

Čiulda, Juozas. 1993.

Daujotyte, Viktorija. 2015.

Girdenis, Aleksas. 1971.

Girdenis, Aleksas. 1981.

Girdenis, Aleksas. 1990.

Girdenis Aleksas. 1994.

Girdenis, Aleksas;

Kačiuškiene, Genovaitė. 1986.

Girdenis, Aleksas; Pabrèža, Juozas. 1998.

Kalnius, Petras. 2012.

Mikulènienė, Danguolé;

Meiliūnaite, Violeta (red.). 2014.

Pabrèža, Juozas. 1986.

Pabrèža, Juozas. 1991.

Pabrèža, Juozas. 2012a.
Tarmès ir tarmiškumo vertè. Visos tarmès gražiausios. Vilnius: Mokslo ir enciklopedijų leidybos centras, 9-13.

Žemaičių pasosakymas. Žemaičiai: Žemaičių rašytojų prozos ir poezijos antologija. Kaunas: Sakalas, 7-15.

Zametki o litovskom" jazyke i slovare. Sanktpeterburg": Otd-nie rus. jaz.i slovesnosti Imperatorskoj AN.

Žemaičių kalba šiandien ir jos išlikimo perspektyvos. Žemaičiu žemé 2(35), 12-13.

Trumpi samprotavimai apie žemaičiu kalbos gramatikos taisykles. Vilnius: Mokslo ir enciklopedijų leidykla.

Tatā pariejau / Tai parëjau. Vilnius: Regionų kultūrinių iniciatyvų centras.

Kada gi žemaičių tarmė atsiskyrẻ nuo aukštaičių? Kalbotyra 22(1), 81-86.

Kuršių substrato problema šiaurès žemaičių teritorijoje (Fonologijos dalykai). Volkaitè-Kulikauskienè, Regina (red.). Ǐ̌ lietuviu etnogenezès. Vilnius: Mokslas, 19-26.

Tarmèse - tikroji kalbos gyvastis. Gimtoji kalba 10, 1-3.

Žemaičių savarankiškos raidos pradžia. Baltistica 28(2), 5-20.

Paraleliniai reiškiniai latvių ir šiaurinių lietuvių veiksmažodžio sistemose. Kalbotyra 37(1), 21-27.

Žemaičiu rašyba. Vilnius-Šiauliai: Žemaičių kultūros draugijos redakcija.

Žemaičiai: XX a. -XXI a. pradžia. Vilnius: Mintis.

XXI a. Pradžios lietuvių tarmès: geolingvistinis ir sociolingvistinis tyrimas (žeméliapiai ir jų komentarai). Vilnius: Briedis.

Diachroninės pastabos apie kirčio atitraukimą šiaurės žemaičių tarmèje. Baltistica 22(2), 53-59.

Žemaičiu rašybos patarimai. Šiauliai: Šiaulių žemaičiu kultūros draugija „Saulaukis“.

Žemaičių tarme ar žemaičių kalba? Profesoriaus Alekso Girdenio (1936-2011) atminimo konferencija. Pranešimu tezès. Vilnius: Vilniaus universiteto leidykla, 48-49. 
Pabrèža, Juozas. 2012b.

Pabrèža, Juozas. 2015.

Pabrèža, Juozas. 2017.

Pabrèža, Juozas. 2018a.

Pabrèža, Juozas. 2018b.

Salys, Antanas. 1933.

Subačius, Giedrius, 1996.

Tautavičius, Adolfas. 1981.

Zinkevičius, Zigmas. 1981.

Zinkevičius, Zigmas. 1994.

Zinkevičius, Zigmas. 2006.
Žemaičių šnektos - bendrinės kalbos turtas. Žemaičiu kultūros savastys. Nuo Vilniaus kalvu prie Baublio slenksčio. Vilnius: Šilalès kraštiečiu draugija, 8-10.

Tarmès - vienas iš etnografinių regionų kertinių akmenų. Etniné kultūra 9, 86-89.

Žemaičiu kalba ir rašyba. Šiauliai: Šiaulių universiteto bibliotekos Leidybos skyrius.

Žemaitiško rašto ištakos ir tradicijos. Kalbos istorijos ir dialektologijos problemos 5. Vilnius: Lietuviu kalbos instituto leidykla, 119-139.

Žemaičių kalbos tapatybès ženklai. Acta humanitarica universiteatis Saulensis. Šiauliai: Šiaulių universiteto leidykla, 187-195.

Kelios pastabos tarmių istorijai. Archivum Philologicum 4, 21-34.

Trys XIX a. bendrinès kalbos modeliai: J. A. Pabréža, J. Čiulda, S. Daukantas. Lietuvių kalbotyros klausimai 36, 51-59.

Žemaičių etnogenezè (archeologijos duomenimis). VolkaitèKulikauskienè, Regina (red.). Iš lietuvių etnogenezès. Vilnius: Mokslas, 27-35.

Žemaičių tarmès kilmès klausimu. Volkaitė-Kulikauskienė, Regina (red.). Iš lietuvių etnogenezès. Vilnius: Mokslas, 12-18.

Lietuviu kalbos dialektologija. Vilnius: Mokslo ir enciklopediju leidykla.

Lietuvių tarmiu kilmè. Vilnius: Lietuvių kalbos institutas.

Juozas Pabrèža

Šiauliai University

P. Višinskio g. 38, LT-76352 Šiauliai, Lietuva

juozas.pabreza@su.lt

\section{KOPSAVILKUMS}

\section{Žemaišu valoda pagātnē un mūsdienās Juozas PABRĖŽA}

Kopš seniem laikiem atkārtoti ir ticis izvirzìts būtisks jautājums: vai žemaišu runātā idioma ir valoda vai dialekts? Pirms mūsdienu lietuviešu rakstu valodas izveidošanās dominēja žemaišu valodas jēdziens. Līdz ar lietuviešu valodas standarta rašanos citas valodu sistēmas sāka parasti saukt par dialektiem vai izloksnēm. Šajā rakstā tiek apgalvots, ka pastāv žemaišu valoda ar trim galvenajiem atšķirīgiem dialektiem - ziemel̦žemaišu jeb dounininku, dienvidžemaišu jeb dūnininku, rietumžemaišu jeb donininku, kas tālāk dalās ziemeḷžemaišu Telšu (telšiškiai) un Kretingas (kretingiškiai), dienvidžemaišu Varņu (varniškiai) un Raseiņu (raseiniškiai) izloksnēs, kā arī daudzās sīkākās apakšizloksnēs.

Svarīgākās pazīmes, kas raksturo žemaišu valodas identitāti ir šādas:

1) žemaišu dialektālā runa būtiski atšksiras gan no lietuviešu rakstu valodas, gan no citiem lietuviešu valodas dialektiem, valodas īpašo stāvokli balsta valodnieku un dialektologu 
uzskats, ka visi lietuviešu dialekti vispirms ir dalāmi divos galvenajos segmentos - žemaišu un aukštaišu (agrāk - žemaišu un lietuviešu);

2) visos žemaišu valodas līmeņos ir diezgan daudz unikālu un arhaisku īpatnību (skaņu, formu un konstrukciju), kas nav atrodamas lietuviešu rakstu valodā vai citos dialektos;

3) žemaišu valodai ir standartizēta rakstība ar skaidriem noteikumiem, saskaņā ar kuriem tiek publicēti daudzi raksti presē, kā arī daiļiteratūra;

4) mūsdienās identifikācija un pašidentifikācija ar dzimto žemaišu valodu Žemaitijā ir ḷoti izteikta un nozīmīga, lielākā dạ̦a žemaišu dialektālo runu uzskata par savu dzimto valodu, savukārt cilvēks, kurš runā žemaitiski, visbiežāk tiek uztverts un pozitīvi definēts kā tas, kurš respektē dzimto valodu. Kopumā žemaišu valodas prestižs ir spēcīgs un joprojām aug.

\section{SANTRAUKA}

\section{Žemaitiu kalbuos praeitès èr dabartès \\ PABRIEŽA Jūzaps}

Nu seniausiu laikū karts nu karta bova kelams klausèms: a ìr žemaitiu kalba, a žemaitiu tarmie? Ligi lietuviu bẻndrènès kalbuos atsėradėma žemaitiu kalbuos sāvuoka bova vartuojama dẻdlē tonkē. Didèlis būrīs riktingu žemaitiu (D. Puoška, S. Stanevičios, J. A. Pabrieža, M. Valončios, S. Daukonts èr kètė) sava darbus raše žemaitěšā. Ka sosẻformava lietuviu bẻndrènė kalba, kètas kalbėnès sistemas paprastā vadènamas tarmiems. Aple žemaitiu kalbuos èr žemaitiu tarmies santīki na veina karta īr ožsèmènè, rašè A. Gèrdènis, J. Pabrieža. Gal sakītè, ka abodo termènā-žemaitiu kalba èr žemaitiu tarmie - īr gerè èr vartuotènè. Šiamè straipsnie prisèlaikuoma nuostatas, ka īr žemaitiu kalba, katra tor tris rǐškès tarmès (šiaurès žemaitē dounininkā, peiitū žemaitē dūnininkā, vakarū žemaitē doninink $\bar{a}$ ), šiaurès žemaitiu telšiškiu èr kretingiškiu, peiitū žemaitiu varniškiu èr raseiniškiu patarmès èr daugībè smolkiesniu šnektū èr šnektieliu.

Svarbiause žemaitiu kalbuos tapatībès ženklā èr tuos kalbuos bovèma īruodīmā būtom tuokèi: 1) žemaitiu tarmènè kalba rīškē skèrās èr nu lietuviu bèndrènès kalbuos, èr nu kètū lietuviu kalbuos tarmių; tou žemaitiu kalbuos ěšskèrtėnoma ruoda kalbininku vėinings sotarėms vėsas lietuviu kalbuos tarmès permiausē skèrstītè i do stombius gabalus: žemaitius ir aukštaitius (dar seniau žemaitius èr lietuvius); 2) žemaitiu kalba tor vėsus svarbiausius kuožnuos kalbuos lïgmėnis

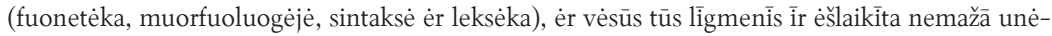
kaliū, senuověšku ỉpatỉbiu, garsū, fuormu, kuonstrukcejju, kuo nabier lietuviu bẻndrènie kalbuo ar kètuos tarmies; 3) žemaitē tor sotvarkîta rašiba, tuos rašíbas taisỉklès, pagal katras žemaitiu kalbo îr spausdènama nemažā publicistèkas straipsniu, gruožènès literatūras kūrèniū, īr leidamè laikraštē, žornalā, èštėsas kningas; 4) šèndèin Žemaitėjuo savès sotapatėnèms, èšreiškems par gimtuojẻ žemaitiu kalba îr dẻdlē rī̌šos èr nuognē svarbos, daug žemaitiu tarmèška kalbiesẻna sopront èr sovuok kāp tékrōjè gimtōjẻ kalba, vuo žemaitèškā basėrokuojẻntis žmuogos dažniausē îr vertènams èr apébūdènams palonkē, kāp gerbōs gimtōjẻ kalba, patrèjuotěškā nusèteikès èr panašě Žemaitiu kalbuos prestižos îr sostèpriejès èr augontis. 